\title{
Theoretical Study on the Position of Protonation of Benzodixanthene Endoperoxide and its Analogs
}

\author{
Tatsuya Tachikawa ${ }^{\mathrm{a}}$, Sumio Tokita ${ }^{\mathrm{a}}$, and Kenichi Somekawa ${ }^{\mathrm{b}}$ \\ ${ }^{a}$ Department of Applied Chemistry, Faculty of Engineering, Saitama University, \\ 255 Shimo-Ohkubo, Saitama, 338-8570 Japan \\ ${ }^{\mathrm{b}}$ Department of Applied Chemistry and Chemical Engineering, Faculty of Engineering, Kagoshima University, \\ 1-21-40 Korimoto, Kagoshima, 890-0065 Japan
}

(Received November 19, 2001; Accepted January 31, 2002)

\begin{abstract}
Colorless endoperoxide (1a) of benzo[1,2,3-kl:4,5,6-k'l']dixanthene (2a) changes into colored 2a in the presence of acid at room temperature. Interaction between 1a and acid was estimated using the AM1 molecular orbital calculation. The calculation shows that 1a reacts with a proton more easily at an endo oxygen atom than at a xanthene oxygen atom, and that the protonated species goes through a carbocation (4a) to give colored 2a. In order to propose novel functional dyes, which change their color more sensitively by the addition of acid, we studied the interaction between protons and the endoperoxides containing nitrogen (1b) or sulfur (1) instead of oxygen. Nitrogen analog $\mathbf{1 b}$ is a hypothetical molecule. The calculated proton affinity of $\mathbf{1 b}$ or $\mathbf{1 c}$ at peripheral heteroatoms was about $34 \mathrm{kcal} \mathrm{mol}^{-1}$ greater than that of $\mathbf{1 a}$. The deoxygenation of endoperoxide (1) to give $\mathbf{2}$ is expected to be accelerated by replacement of the peripheral heteroatoms. Replacement of the peripheral heteroatom from oxygen to nitrogen also showed larger proton affinity in case the protonation would take place at the endo oxygen. Such replacement of the peripheral atoms would be effective modification for the acceleration of color forming reaction because of their greater proton affinity.
\end{abstract}

Key Words: Molecular orbital calculation, AM1 method, Benzodixanthene, Endoperoxide, Proton affinity, Protonation, Functional dye, Color former, Deoxygenation

\section{Introduction}

Photooxidation

of benzo[1,2,3-kl:4,5,6-k'l']dixan-thene (2a) using visible light produces colorless endoperoxide (1a), and 1a

*tokita@apc.saitama-u.ac.jp 
returns to colored $\mathbf{2 a}$ by refluxing in toluene[1,2]. Various derivatives of $\mathbf{2 a}$ have been synthesized[3]. Recently, we found that $\mathbf{1 a}$ changes to colored $\mathbf{2 a}$ at room temperature in the presence of acid (Scheme 1)[4].

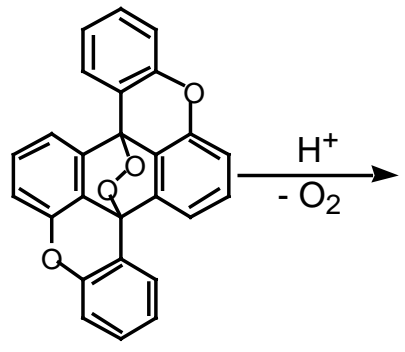

1 Colorless

Scheme 1<smiles>[X]c1ccccc1C1([X])c2ccccc2C(O)(c2ccccc2[X])c2ccccc21</smiles><smiles>C[PH+]C</smiles>

1a-c

2a Colored

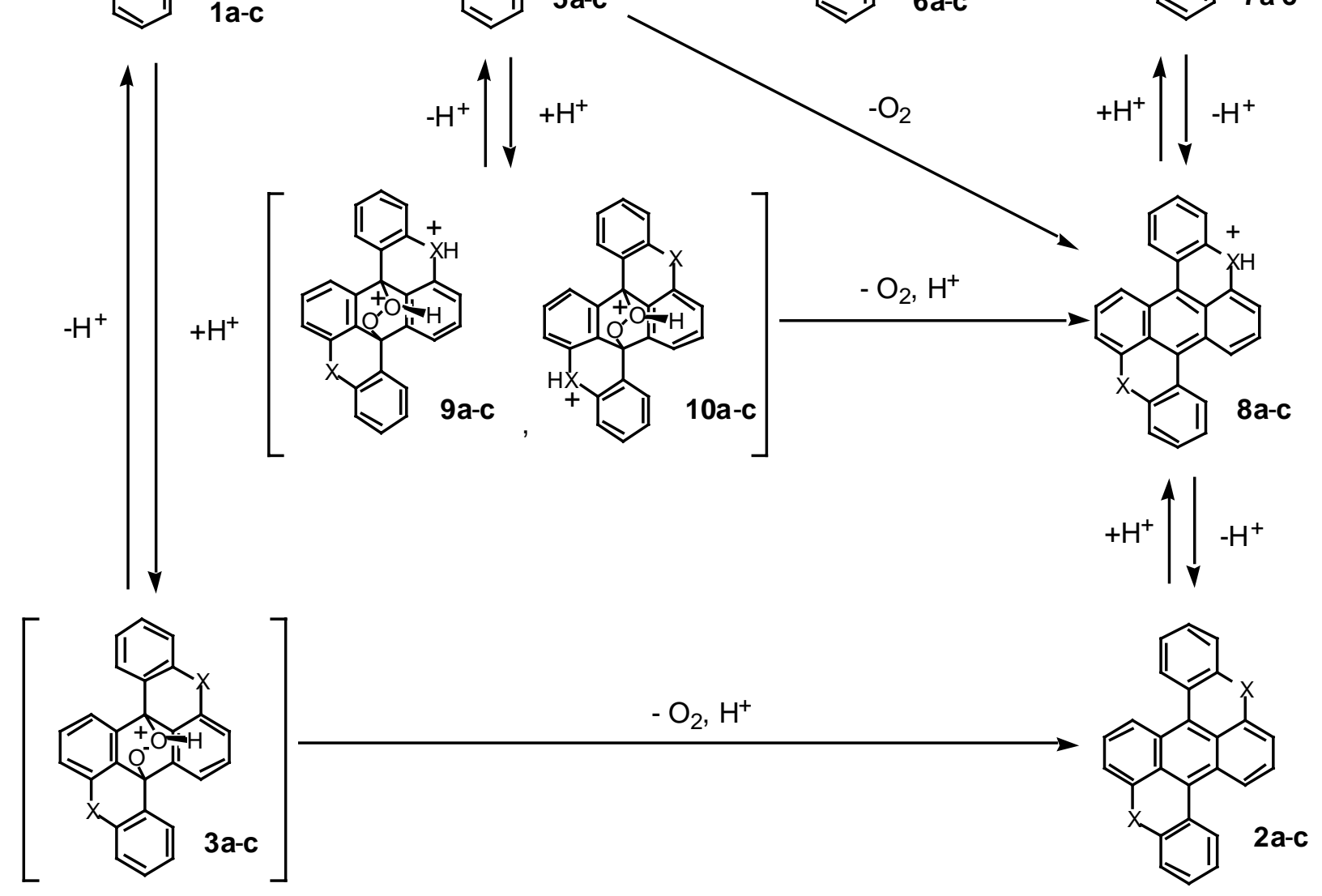

The investigation of the functional dyes, which change their color sensitively by the addition of acid, would be notable because they can be utilized as an indicator, for example, as a $\gamma$ ray detecting system[4]. We used the molecular orbital method to calculate the interaction between endoperoxide and acid, and designed the sensitive endoperoxide analogs containing nitrogen (1b) or sulfur (1c)[5] instead of oxygen. Nitrogen analog $\mathbf{1 b}$ is a hypothetical molecule only used for calculation.

The possible reactions from $\mathbf{1}$ to $\mathbf{2}$ in the presence of acid are summarized in Scheme 2.

\section{Method}

The initial structures of 1a-c were built using the MM2 calculation[6,7]in the Chem 3D software[8]. Initial

Scheme $2(\mathbf{a}: X=O, \mathbf{b}: X=N H, \mathbf{c}: X=S)$ 
geometry of protonated species such as $\mathbf{3}$ or $\mathbf{5}$ was assumed to have $\mathrm{O}-\mathrm{H}$ bond length of $1.1 \AA$, H-O-C bond angle of $109.48^{\circ}$ and H-O-C-C dihedral angle of $120^{\circ}$. The structure was optimized using the AM1[9] method in the Win-MOPAC 97[10] on a personal computer. The structural optimization of the protonated species was carried out with the key words, EF, Precise, and charge $=$ +1 or +2 .

\section{Results and Discussion}

\section{Protonation to 1a}

In order to confirm the reaction route, we have compared the heat of formation of protonated species $\mathbf{3 a}$ with that of 5a. To build up the geometry of $\mathbf{3 a}$ or $\mathbf{5 a}$ under the conditions where the $\mathrm{H}-\mathrm{O}-\mathrm{C}$ bond angle is fixed to $109.48^{\circ}$, two isomers were considered. These are 3a-1 and 3a-2, or 5a-1 and 5a-2, respectively, as shown in Scheme 3. For 3a-1 and 3a-2, the configutration of the chirality center at the protonated oxygen is R for 3a-1 and S for 3a-2. For 5a-1 and 5a-2, the configutration of the chirality center at the protonated oxygen is R for $\mathbf{5 a - 1}$ and $\mathrm{S}$ for $\mathbf{5 a - 2}$.
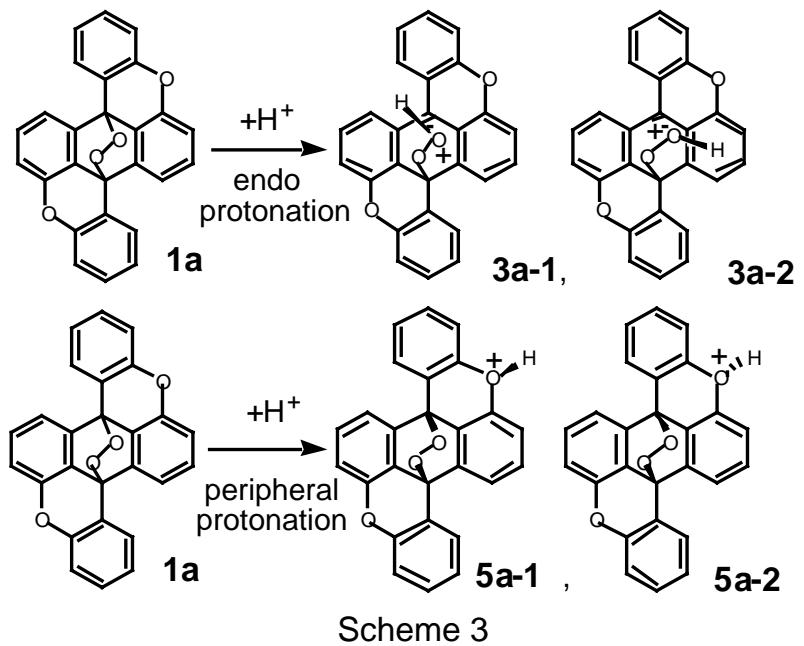

The protonated species at the peripheral position, 5a-1 and 5a-2 showed only a small geometrical change after the geometrical optimization. On the other hand, the protonated species at endo position, 3a-1 and 3a-2 showed a drastic change in its geometry to give carbocation 4a as shown in Scheme 4.

In the course of geometrical optimization of $\mathbf{3 a - 1}$ and 3a-2, the bond between the protonated oxygen atom and the bridgehead carbon was cleaved. The geometry of $\mathbf{4 a}$, which was obtained from geometrical optimization of
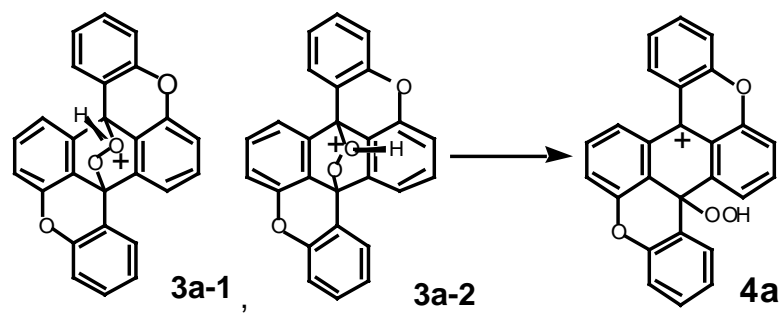

Scheme 4

3a-1, is shown in Figure 1. Ab initio calculation (HF/3-21G) gave a carbocation structure similar to that from AM1 calculations. The structures with a hydroperoxy moiety have been obtained in the ene-reaction with singlet oxygen[11] or in the oxidations of endoperoxide in water[12].

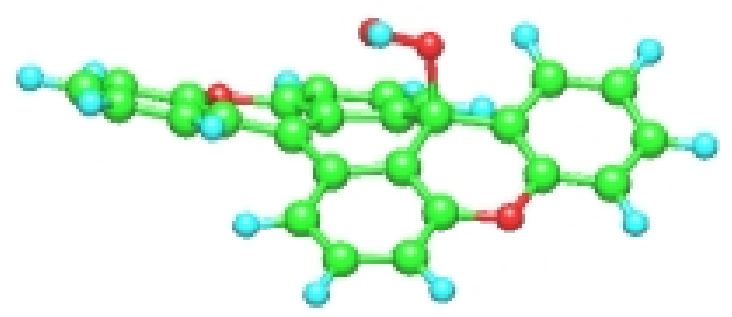

Figure 1. Optimized geometry of $\mathbf{4 a}$

The calculated heat of formation of $\mathbf{4 a}$ was much smaller than that of $\mathbf{5 a}$ (Table 1). Thus, 1a would be protonated at an endo oxygen more easily than at a peripheral oxygen, and the compound $4 \mathbf{a}$ may be favored at this stage.

Table 1. Heats of formation, $\Delta \mathrm{H}_{\mathrm{f}}\left(\mathrm{kcal} \mathrm{mol}^{-1}\right)$ of $\mathbf{1 a}$ and its protonated species, $4 \mathbf{a}$ and $\mathbf{5 a}$, calculated using AM1 MO method.

\begin{tabular}{ccc}
\hline Compound & Heat of formation $\left(\Delta \mathrm{H}_{\mathrm{f}}\right)$ & $\Delta \Delta \mathrm{H}_{\mathrm{f}}$ \\
\hline $\mathbf{1 a}$ & 92.28 & \\
$\mathbf{4 a}$ & 229.27 & \\
$\mathbf{5 a - 1 , 5 a - 2}$ & $284.16,284.23$ & 0.07 \\
\hline
\end{tabular}

Two values of heat of formation shown in the column of Table 1 for $\mathbf{5 a}$ correspond to the isomers, 5a-1 and 5a-2, respectively. The difference in the heat of formation between the two isomers of $\mathbf{5 a}\left(\Delta \Delta \mathrm{H}_{\mathrm{f}}\right)$ was $0.07 \mathrm{kcal} \mathrm{mol}^{-1}$. Thus, the difference in heat of formation was so small that we dealt with only one of the isomers in this paper.

Equation(1) shows that the protonated 4 a reacts with chloride anion when $1 \mathbf{a}$ reacts with hydrochloric acid. The reaction would easily produce the colored compound 2a and oxygen exothermally. 


$$
\mathbf{4 a}+\mathrm{Cl}^{-}-\mathbf{2} \mathbf{a}+\mathrm{HCl}+\mathrm{O}_{2}+136.7 \mathrm{kcal} \mathrm{mol}^{-1}
$$

However, the coloring reaction of compound 1a with small amount of acid proceeds so slowly that novel endoperoxides, which are more sensitive to acid, have been needed for the $\gamma$-rays dosimeter.

In order to promote the coloration to be more rapid, we designed the replacement of the xanthene oxygen atoms of 1a with nitrogen or sulfur atoms with the expectation of easier protonation to the endo oxygen or the peripheral position of the endoperoxides to facilitate the easy deoxygenation. We investigated the proton affinities[13] of compounds $\mathbf{1 b}$ and $\mathbf{1 c}$ in Scheme 3 using the AM1 method.

\section{Effect of replacement of peripheral heteroatoms}

As the heats of formation cannot be directly compared among molecules constructed from different components, the effect of the replacement of the heteroatoms was compared using proton affinity. Proton affinity of fundamental molecules has been calculated using various MO methods [13]. The proton affinity of a compound $\mathrm{X}$ which gives $\mathrm{XH}^{+}$by protonation, (PA $\left(\mathrm{X}->\mathrm{XH}^{+}\right)$), was estimated by the equation (2) using the heat of formation calculated by semi-empirical MO method such as AM1,

$\mathrm{PA}\left(\mathrm{X}->\mathrm{XH}^{+}\right)=-\Delta \mathrm{H}_{\mathrm{f}}\left(\mathrm{XH}^{+}\right)+\Delta \mathrm{H}_{\mathrm{f}}\left(\mathrm{H}^{+}\right)+\Delta \mathrm{H}_{\mathrm{f}}(\mathrm{X})$

where $\Delta \mathrm{H}_{\mathrm{f}}(\mathrm{X})$ and $\Delta \mathrm{H}_{\mathrm{f}}\left(\mathrm{XH}^{+}\right)$are heats of formation of compound $\mathrm{X}$ and its protonated species $\mathrm{XH}^{+}$, respectively. Heat of formation of a proton, $\Delta \mathrm{H}_{\mathrm{f}}\left(\mathrm{H}^{+}\right)$is the electronic energy of $1 \mathrm{~s}$ orbital, $313.51 \mathrm{kcal} \mathrm{mol}^{-1}$. The results calculated using this equation (2) are shown in Table 2.

Table 2. Proton affinities, PA (kcal mol $\left.{ }^{-1}\right)$ of $\mathbf{1 a}-\mathbf{c}$ to give $4 \mathbf{a}-\mathbf{c}$ or $\mathbf{5 a}$ - c calculated using AM1 MO method.

\begin{tabular}{ccc}
\hline & PA $(\mathbf{1}$-> 4) & PA $(\mathbf{1}$-> 5) \\
\hline a $(\mathrm{X}=\mathrm{O})$ & 178.7 & 121.6 \\
$\mathbf{b}(\mathrm{X}=\mathrm{NH})$ & 189.5 & 156.3 \\
c $(\mathrm{X}=\mathrm{S})$ & 178.5 & 155.8 \\
\hline
\end{tabular}

The calculated proton affinities of $\mathbf{1 b}$ or $\mathbf{1 c}$ at peripheral heteroatoms to give $\mathbf{5 b}$ or $\mathbf{5 c}$ were about 35 kcal mol ${ }^{-1}$ larger than that of $\mathbf{1 a}$ to give $\mathbf{5 a}$ due to the replacement of the peripheral heteroatoms from oxygen atoms to nitrogen or sulfur atoms. On the other hand, the proton affinities of $\mathbf{1 b}$ to give $\mathbf{4 b}$ showed the $11 \mathrm{kcal}$ $\mathrm{mol}^{-1}$ larger values than those of $\mathbf{1 a}$ or $\mathbf{1 c}$ to give $\mathbf{4 a}$ or 4c.

We compared the hypothetical protonated species 3a-c and 5'a-c to consider to which heteroatoms proton would approach. The optimization of 3a-c and 5'a-c are carried out only around the additional proton atom. They might correspond to the early stage in protonation before optimized structures $\mathbf{4 a - c}$ and $\mathbf{5 a - c}$, respectively. The input data for AM1 calculations of 3a-c and 5'a-c were prepared from a free proton and the optimized structure of 1a-c which have been fixed through the SCF calculations. The results are shown in Table 3.

Table 3. Proton affinities ${ }^{\mathrm{a}}\left(\mathrm{kcal} \mathrm{mol}^{-1}\right)$ of $\mathbf{1 a}-\mathbf{c}$ to give 3a - c and 5'a - c calculated using AM1 MO method.

\begin{tabular}{cccc}
\hline & $\operatorname{PA}(\mathbf{1}->\mathbf{3})$ & $\mathrm{PA}\left(\mathbf{1}->\mathbf{5}^{\prime}\right)$ & $\Delta \mathrm{PA}\left[(\mathbf{1}->\mathbf{3})-\left(\mathbf{1}->\mathbf{5}^{\prime}\right)\right]$ \\
\hline $\mathbf{a}$ & 133.6 & 115.8 & 17.8 \\
$\mathbf{b}$ & 140.3 & 149.6 & -9.3 \\
$\mathbf{c}$ & 134.2 & 155.1 & -20.9 \\
\hline
\end{tabular}

a) the geometry of the endoperoxide moiety was fixed.

The calculation indicated that the benzodixanthene endoperoxide 1a would have the selectivity in proton addition to give $\mathbf{3 a}$ as the positive value was obtained in $\triangle \mathrm{PA}$. But 1b and 1c showed easier protonation at peripheral heteroatoms to give $\mathbf{5 b}$ and $\mathbf{5 c}$ than $\mathbf{3 b}$ and $\mathbf{3 c}$ as the negative values were obtained in $\triangle \mathrm{PA}$. Deoxygenation of $\mathbf{5}$ to give the dye $\mathbf{2}$ must take place more easily than in case of $\mathbf{4}$. To make sure that the deoxygenation of $\mathbf{5} \mathbf{b}$ would take place more easily than that of $\mathbf{1 b}$, the transition states of deoxygenating process were calculated. The results are shown in Tables 4 and 5.

Table 4. Energies in transition state TS and $\Delta \mathrm{E}(\mathbf{1}->\mathrm{TS})$ values $\left(\mathrm{kcal} \mathrm{mol}^{-1}\right)$ of the deoxygenating reaction of $\mathbf{1}$ to give 2 and $\mathrm{O}_{2}$.

\begin{tabular}{rrrrc}
\hline & \multicolumn{1}{c}{$\mathbf{1}$} & $\mathrm{TS}$ & $\mathbf{2}+\mathrm{O}_{2}$ & $\Delta \mathrm{E}(\mathbf{1 - >} \mathrm{TS})$ \\
\hline $\mathbf{a}$ & 92.3 & 116.6 & 79.5 & 24.3 \\
$\mathbf{b}$ & 151.4 & 175.2 & 139.6 & 23.8 \\
$\mathbf{c}$ & 149.0 & 175.2 & 140.8 & 26.2 \\
\hline
\end{tabular}

Table 5. Energies in transition state TS and $\Delta \mathrm{E}(\mathbf{5}->\mathrm{TS})$ values $\left(\mathrm{kcal} \mathrm{mol}^{-1}\right)$ of the deoxygenating reaction of 5 to give 8 and $\mathrm{O}_{2}$.

\begin{tabular}{ccccc}
\hline & $\mathbf{5}$ & $\mathrm{TS}$ & $\mathbf{8}+\mathrm{O}_{2}$ & $\Delta \mathrm{E}(\mathbf{5}->\mathrm{TS})$ \\
\hline $\mathbf{a}$ & 284.2 & 306.5 & 264.1 & 22.3 \\
$\mathbf{b}$ & 308.6 & 330.2 & 290.7 & 21.6 \\
$\mathbf{c}$ & 306.9 & 330.2 & 290.8 & 23.3 \\
\hline
\end{tabular}


Table 4 shows the transition energies $(\Delta \mathrm{E})$ of $\mathbf{1}$ to give $\mathbf{2}$ and $\mathrm{O}_{2}$, and Table 5 shows those of $\mathbf{5}$ to give $\mathbf{8}$ and $\mathrm{O}_{2}$, respectively. The transition energies $(\Delta \mathrm{E})$ show similar values in spite of the difference in $\mathrm{X}$. The $\Delta \mathrm{E}(\mathbf{5}$ -> TS) were 1 - $3 \mathrm{kcal} \mathrm{mol}^{-1}$ smaller than $\Delta \mathrm{E}(\mathbf{1}->\mathrm{TS})$. The difference is lather small. It suggests that the coloring reaction to give dyes would not be accelerated so much by the protonation at peripheral heteroatom $\mathrm{X}$, as the coloring reaction of $1 \mathrm{a}$ at $100^{\circ} \mathrm{C}$ would become to take place at room temperature by the protonation.

\section{Protonation to 5}

The further protonation at peripheral or endo position of 5a-c produces 6a-c, 9a-c or 10a-c. Proton affinities of 5a-c to give 6a-c, 9a-c or 10a-c were calculated by the same manner with 1a-c. 9a-c and 10a-c also showed the drastic geometrical change to 11a-c and 12a-c, respectively (Scheme 5).

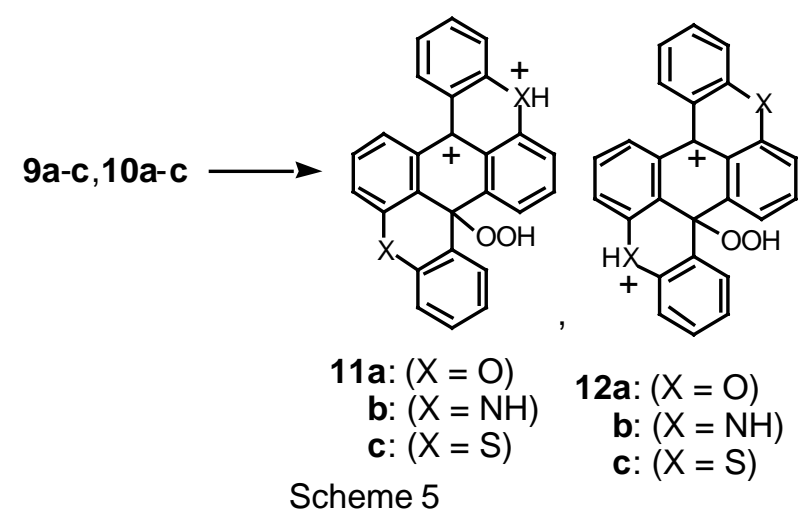

The calculated results are shown in Table 6. The proton affinities of 5a-c at a peripheral heteroatom to give 6a-c were $47-55 \mathrm{kcal} \mathrm{mol}^{-1}$ smaller than those of 1a-c to give 5a-c. The proton affinities of 5a-c at an endo oxygen to give 12a-c were $60-62 \mathrm{kcal} \mathrm{mol}^{-1}$ smaller than those of 1a-c to give 4a-c. So, the protonation at a peripheral heteroatom would take place easier than those at a endo oxygen in 5a-c compared with $\mathbf{1 a}$ - c.

Table 6. Proton affinities $\left(\mathrm{kcal} \mathrm{mol}^{-1}\right)$ of mono-protonated species $(5 \mathbf{a}-\mathbf{c})$ to give 6, 11 and 12 calculated using AM1 MO method.

\begin{tabular}{lccc}
\hline & PA $(\mathbf{5}$-> 6$)$ & PA $(\mathbf{5}$ - $\mathbf{~ 1 1})$ & PA $(\mathbf{5}$-> 12) \\
\hline a & 68.1 & 93.4 & 115.6 \\
b & 109.6 & 96.3 & 126.5 \\
$\mathbf{c}$ & 102.6 & 93.8 & 118.3 \\
\hline
\end{tabular}

\section{Conclusion}

Benzodixanthene endoperoxide 1a was shown to react with proton at endo oxygen more easily than at xanthene oxygen from the calculation of proton affinity using the AM1 method. We have designed the nitrogen analog $\mathbf{1 b}$ and sulfur analog 1c. The proton affinities of $\mathbf{1 b}$ and 1c at peripheral heteroatoms became about $34-$ $39 \mathrm{kcal} \mathrm{mol}^{-1}$ larger than that of 1a. The proton affinity of $\mathbf{1 b}$ at the endo oxygen showed larger value than that of $1 \mathbf{a}$ or 1c. The transition energies $\Delta \mathrm{E}(\mathbf{5 a}-\mathbf{c}->\mathrm{TS})$ were 1 - $3 \mathrm{kcal} \mathrm{mol}^{-1}$ smaller than $\Delta \mathrm{E}(\mathbf{1 a}-\mathbf{c}->\mathrm{TS})$. The coloring reaction to give dyes by the protonation at the endo oxygen of $\mathbf{1 b}$ would be accelerated by the replacement of the peripheral heteroatoms to nitrogen. The proton affinity would be important to accelerate the deoxygenation to give 2 .

\section{Acknowledgement}

The authors acknowledge the Grand-in-Aid H12-007 for JAERI's Nuclear Research Promotion Program from Japan Atomic Energy Research Institute.

\section{References}

[1] H. -D. Brauer and R. Schmidt, "Photochromism. Molecules and Systems," $\mathrm{H}$. Durr and $\mathrm{H}$. Bouas-Laurent eds., Elsevier, Amsterdam 1990, p 631.

[2] R. Schmidt, W. Drews, and H. -D. Brauer, J. Photochem., 18, 365 (1982).

[3] S. Tokita, "Photochromism Based on the Photosensitizd Oxygenation of Polycondensed Aromatic Compounds" (in Japanese), Kikan Kagaku Sosetsu, 28, 135 (1996).

[4] S. Tokita, K. Nagahama, and T. Watanabe, Mol. Cryst. and Liq. Cryst., 345, 185 (2000).

[5] S. Tokita, S. Suge, M. Toya, and H. Nishi, Nippon Kagaku kaishi, 97 (1988).

[6] N. L. Allinger, J. Am. Chem. Soc., 99, 8217 (1977).

[7] N. L. Allinger, J. Comput. Chem., 1, 30 (1980).

[8] CS Chem3D Pro, ver. 5.0, Cambridge Software Co., 1999.

[9] M. J. S. Dewar, E. G. Zoebisch, and E. F. Healy, J. J. P. Stewart, J. Am. Chem. Soc., 107, 3902 (1985).

[10] MOPAC 97 in WinMOPAC ver. 2.0. Fujitsu.

[11] K. Gollinick, and H. J. Khun, "Ene-Reaction with Singlet Oxygen", H. H. Wasserman, and R. W. Murray eds., "Singlet Oxygen", Academic Press, 
New York 1979.

[12] I. Saito, and T. Matsuura, "The Oxidations of Electron-Rich Aromatic Compounds", H. H. Wasserman, and R. W. Murray eds., "Singlet
Oxygen", Academic Press, New York 1979.

[13] J. L. Ozment, and A. M. Schmiedekamp, Int. J. Quantum Chem. 43, 783 (1992). 


\title{
ベンゾ[1,2,3-kl:4,5,6-k'l’]ジキサンテンエンドペルオキシド 類縁体のプロトン化物に関する理論化学的研究
}

\author{
太刀川 達也 ${ }^{\mathrm{a}}$, 時田 澄男 ${ }^{\mathrm{a}^{*}}$, 染川 賢一 ${ }^{\mathrm{b}}$
}

a埼玉大学工学部応用化学科, ₹ 338-8570 埼玉県さいたま市下大久保 255

’ 鹿児島大学工学部応用化学工学科, ₹ 890-0065 鹿児島県鹿児島市郡元1-21-40

酸を添加することによりエンド酸素が脱離し着色するベンゾ[1,2,3-kl:4,5,6-k'l']ジキサンテン エンドペルオキシド(1a)と光の室素類縁体 $(\mathbf{1 b})$ またはイオウ類縁体(1c)について, AM1分子軌道 法計算によりプロトンとの反応性, および, 色素骨格の周辺部に位置するへテロ原子の違いが 脱酸素反応に与える影響について検討した . まず、酸素類縁体(1a)については, エンド酸素のプ ロトン親和性が色素部位の酸素のプロトンの親和性に比べて大きく, エンド酸素へのプロトン 化によって生成する中間体 $\mathbf{4 a}$ を経て色素体に分解することが推定された. しかし，兴の反応 が実験的に遅いことから、色素部位のへテロ原子を硫黄や室素に換えることによる効果をシミ ユレートした . 色素部位のプロトン親和性は大きくなり、また、弚のへテロ原子にプロトンが 付くことにより, 酸素の脱離反応の活性化エネルギーが軽減され, 酸素の脱離がおこり易くな ることが計算により示唆された . 一方、特に室素のとき、4 を経由するエンド酸素へのプロト ン化反応が有利であった .これらのことにより周辺部のへテロ原子を酸素から室素や硫黄に変 換することにより，エンドペルオキシドの酸との着色反応を促進できると期待できる . 酸を卜 リガーとする新しい機能性色素を見出す指導原理になると考えられる．

キーワード:半経験的分子軌道法計算, AM1法, ベンゾジキサンテン, エンドペルオキシド, プロトン 親和性 , プロトン化物，機能性色素，カラーフォーマー，脱酸素反応

\footnotetext{
*tokita@apc.saitama-u.ac.jp
} 